\title{
Factors Driving Customer Satisfaction at Shopping Mall Food Courts
}

\author{
Maram A. Mahin ${ }^{1}$, Iman M. Adeinat ${ }^{1}$ \\ ${ }^{1}$ King Abdulaziz University, Jeddah, Saudi Arabia \\ Correspondence: Iman M. Adeinat, Business Administration Department, Faculty of Economics and \\ Administration, Jeddah, Saudi Arabia.
}

Received: January 2, 2020

Accepted: January 30, 2020

Online Published: February 10, 2020

doi:10.5539/ibr.v13n3p27

URL: https://doi.org/10.5539/ibr.v13n3p27

\begin{abstract}
In the service industry, when providers generate a high level of customer satisfaction, they can gain and maintain a major competitive advantage in the marketplace. This competitive advantage can, in turn, lead directly to high profitability and growth. In the present competitive consumer landscape, world, shopping malls must deliver high-quality service to customers given that as a service ecosystem the mall must optimize its own resources and the resources of others to improve both its own circumstances and those of others. Against this general background, in this study, we assess the quality attributes of a food court located in a shopping mall by identifying factors related to the shopping mall-ambience, food variety, convenience, the tenants in the food court, food quality, food price, and restaurant staff. A descriptive analysis and a multivariate analysis, including structural equation modeling, are performed using IBM SPSS and AMOS statistical software. The results of the factor analysis indicate that food quality, followed by convenience and food variety, is the most important factor driving customer satisfaction. The results highlight the importance of networks between different stakeholders in such an ecosystem and provide developers and service providers with information in regard to the attributes most implicated in predicting customer satisfaction in a food court. On this basis, customers are viewed not only as evaluators but also as partners in producing service.
\end{abstract}

Keywords: customer satisfaction, food court, service ecosystem, service quality, shopping mall

\section{Introduction}

The retail environment of a shopping mall can be considered a service ecosystem (Yiu \& Yau, 2006). That is, shopping malls are governed by the service-dominant logic as that governing a service ecosystem, the latter of which is defined as a "relatively self-contained, self-adjusting system of resource-integrating actors connected by shared institutional arrangements and mutual value creation through service exchange" (Vargo \& Lusch, 2016, p. 161). The service-dominant (S-D) logic provides a narrative of value cocreation that is coordinated through actor-generated institutions, institutional arrangements, a service ecosystem, actors, resource integration and service-for-service exchange.

In this context, the defining value of a shopping mall is the interactions that contribute to the value co-creation process. The shopping mall in this regard must provide a cross-category assortment of utilities and services to shoppers, such as retail stores, interactive entertainment places, dining places, play areas, and cinemas to create a positive mall image (Ailawadi \& Keller, 2004; Chebat, Sirgy, \& Grzeskowiak, 2010). The greater the breadth of products and services available, the greater the range of situations in which consumers recall and consider the retailer (Keller, 2003), and, therefore, the more salient the retailer which is the most basic building block for establishing a brand (Keller, 2003).

Given that value co-creation through a service-for-service exchange is at the very heart of the shopping mall, we focus on the exchange that occurs in shopping mall food courts with a goal of identifying the service-quality attributes that are most important in driving customer satisfaction. For this reason, we will assess the service quality in a food court from the perspective of the customers and in relation to the overall food court, the restaurants within it, and in relation to the shopping mall itself.

The literature focused on the food industry includes many studies that rely on the service-quality dimensions tangible, reliability, responsiveness, assurance, and empathy identified by the DINESERV (Stevens et al., 1995) as directly affecting customer satisfaction (Cao \& Kim, 2015; Kuo, Chen \& Cheng, 2018; Stevens et al., 1995). Research on shopping malls, however, has tended to focus on the attributes of the shopping mall itself. For 
example, Diallo et al. (2018) explored both tangible and intangible factors of service quality in a shopping mall, such as the effects of its physical aspects, perceived reliability, personnel, and problem-solving capacity on customer satisfaction with the mall and customer loyalty to it.

In the present study, in order to assess the factors that lead to customer satisfaction, we incorporate some of the attributes identified in previous research on dimensions of service quality related to both shopping malls and restaurants. To that end, as the literature does not include an instrument specifically designed to measure service quality in food courts, we develop a data-collection instrument for use in exactly that setting. This study contributes to the literature through the development of an instrument designed to assess service quality in a food court setting and the identification of the dimensions most strongly related to perceptions of service quality. Our study provides a rationale based on which developers can design and redesign malls to take account of these perceptions, which can be expected to lead to positive results in terms of high customer satisfaction and, therefore, customer loyalty to those malls.

The remainder of this paper is organized as follows. In Section 2, we review the theoretical background on service quality in shopping malls and develop our research hypotheses. We outline the research methodology in Section 3 along with the data-collection procedure and the variables and the ways in which we measured and validated these. Section 4 presents the structural models used and our evaluation of their performance. Finally, we clarify the results and offer a discussion of the implications of our research findings in Section 5.

\section{Theoretical Background and Hypothesis Development}

\subsection{Theoretical Background}

Customers are becoming critical agents in the S-D logic given that they are increasingly playing the role of co-creators in developing services such that these adapt to their perceptions. In fact, as Qin and Prybutok (2008) have argued, customers' assessments of service quality are an important source of information for service providers, enabling the latter to measure performance in terms of quality and then take steps to improve it. Thus, a service provider can offer services superior to those of its competitors, thereby creating a competitive advantage.

It is evident that in shopping malls, certain mall characteristics lead to positive customer satisfaction. Teller (2008) investigated the agglomeration format (AF) of shopping malls and identified nine distinctive AF characteristics: accessibility, parking, retail tenant mix, non-retail tenant mix, merchandise value, personnel, atmosphere, orientation, and infrastructure. According to their findings, customers assigned the greatest importance to retail tenant mix and atmosphere. Similarly, Yiu and Xu (2012) found that the attractiveness of a mall depends to a large extent on the tenant mix scheme.

In other studies, in this general area, researchers identified additional dimensions of service quality such as convenience and location. For example, using structural equation modeling, Ali (2013) identified the factors that may strengthen the attributes of shopping malls and exert an influence on consumers' decisions in regard to visiting shopping malls. He highlighted entertainment, variety, mall essence, and design as the factors with the most influence on consumer decision making.

In addition, El Hedhli et al. (2013) concluded that if customers experience pleasure during their shopping trips to malls, they will develop a more positive attitude toward shopping than wen this is not the case. Ultimately, very positive experiences may be transformed into positive behavioral responses such as customers' engaging in positive word of mouth about his/her experiences at a mall. Khong and Ong (2014) also found that when customers had positive perceptions of the style, variety, and quality of the products and services available at a shopping mall, the result was patronage loyalty. Similarly, according to Babin and Darden (1995), there is a connection between enjoyment and customers' perceptions of service quality.

To that end we formed our hypothesis regarding the attributes of shopping mall and food courts based on the related literature, our main attributes were ambience, convenience, variety of food, price, food quality and staff.

\subsection{Hypothesis Development Related to Food Court Attributes}

Atmosphere or ambience is an important consumer indicator of the quality of shopping malls (Smith \& Burns, 1996). Raajpoot (2002) argued that although ambient factors such as temperature, light, and noise are not a focus of restaurant service, issues with any one of these can lead to concern on the part of customers and can even inconvenience them. Ahmad (2012) assessed the effect of the aesthetics of shopping malls and found that when customers considered the aesthetics to be pleasing as opposed to when this was not the case that customers experienced a higher degree of enjoyment. 
Wright et al. (2006) argued that positive customer perceptions of the mall atmosphere and a sense of pleasure while shopping give rise to an increased desire to remain in the mall and also means that the customers were likely to be satisfied with their experience at the mall. In the same vein, researchers have focused on the ambience of dining service such as food courts in malls, and food courts in colleges (Baker et al., 1994; Wall \& Berry, 2007).

In addition, Ryu et al. (2012) argued that the physical environment in relation to matters such as lighting, decor, design, and employees' appearance can have a significant effect on customer satisfaction. In general, the literature offers vast evidence showing that pleasing aesthetics in relation to mall layout, interior, color, lighting, noise, temperature, and architectural design have a positive impact on the emotions of shoppers and their cognitive evaluation of malls as a viable retail platform, thus driving their satisfaction (Das \& Varshneya, 2017; Idoko, Ukenna, \& Obeta, 2019). Thus, we present Hypothesis 1:

H1: Pleasing food court ambience (cleanliness, decor, lighting, noise, etc.) has a positive effect on customer satisfaction.

Singh and Prashar (2013) argued that shoppers tend to favor retail modes that enhance temporal and spatial convenience. Customers in shopping malls usually place greater emphasis on various dimensions of convenience than on other dimension such as related to other dimensions in order to complete their tasks quickly and then leave the retail mode (Idoko et al., 2019).

Kim et al. (2009) assessed the impact of convenience on the satisfaction and return intention of students in relation to dining facilities at a public university in the Midwest. The researchers found that a convenient location is important to students, as dining at such a place saves them time in comparison with alternatives outside the university. In fact, the results showed that a convenient location was associated with a higher level of satisfaction and an increased return intention as compared with a relatively inconvenient location. Similarly, Ahmad (2012) found that a shopping mall with a high level of convenience, as measured in terms of location and hours of operation, has a positive effect on the relationship between customer satisfaction and the attractiveness factors. Thus, we present Hypothesis 2:

\section{H2: Convenience (location, hours of operation, etc.) has a positive effect on customer satisfaction.}

In general, shopping malls house mainly retail tenants, although there are also some non-retail tenants, which help drive customer satisfaction. Teller (2008) found a non-retail tenant mix in a shopping mall to be an important determinant of shopping mall attractiveness. Given that this is the case, a food court should offer a variety of restaurants with a range of cuisines, possibly including some that, for example, cater to special diets.

According to Raajpoot (2002), food variety is a product/service factor that is expected to contribute substantially to building a favorable image in terms of the quality delivered to the customer. In the context of university dining halls, Kim et al. (2006) found that menu variety had a significant positive effect on students' overall satisfaction with their dining experience with the university food court. In a similar vein, Kwun (2011) found that the relative variety of the menu choices offered in university dining halls had a significant effect on perceived value: i.e., the more varied the menu, the higher the perceived value of the dining experience.

Thus, we present Hypothesis 3:

\section{H3: A large variety of food choices offered at a restaurant has a positive effect on customer satisfaction.}

\subsection{Hypothesis Development Related to Restaurant Attributes}

Price and value are important dimensions affecting customer satisfaction, which in turn determines revisit intentions in the commercial and institutional food service industries (Kim et al., 2009). El Hedhli et al. (2013) included merchandise value as a factor in assessing the functionality of shopping malls. Klassen et al. (2005) argued that price is the most important criterion, with $62 \%$ of respondents choosing that factor. Even though most of a food outlet's pricing is already discounted, price is still the main concern for students in making food purchase decisions. In a restaurant setting, Tsai (2018) used six items - reasonable price, spending limits, in line with local cost, value for money, preference despite higher cost, and affordable price - to assess the perceived monetary price of dining in a restaurant. Based on these items, it was shown that perceived value predicts customer loyalty. Thus, we present Hypothesis 4:

\section{H4: Low food prices have a positive effect on customer satisfaction.}

Food quality has been identified in many studies as a fundamental factor in terms of customer satisfaction with a dining experience (Josiam et al., 2017; Kim, Hertzman, \& Hwang, 2010; Wu \& Mohi, 2015). In several studies, researchers have empirically investigated the relationship between food quality and customer satisfaction. For 
example, Namkung and Jang (2007) assessed the relative importance of food quality attributes and their relationship with customer satisfaction with the mean value between two variables: satisfaction measurement and food quality attributes (presentation, menu item variety, healthy options, taste, freshness, and temperature). The results of the study showed that presentation, taste, and temperature have a significant relationship with satisfaction. In addition, Sulek and Hensly (2004) and Susskind and Chan (2000) found that food quality is considered a significant element affecting customers' perceptions of and satisfaction with a dining experience. Finally, Azanza (2001) endeavored to establish the food purchase and consumption patterns of university students and concluded that the most important factors in securing customer satisfaction in the university context are the healthfulness, affordability, and variety of the foods. Thus, we present Hypothesis 5:

\section{H5: The provision of high-quality food has a positive effect on customer satisfaction.}

Employees play an important role in the service industry, as they have a significant impact on the level of service provided and the profits of the organization. In order to differentiate between services that provide satisfaction to customers from services that do not, Bitner et al. (1990) studied 700 encounters selected according to the critical incident method. These encounters were divided into categories according to the behavior of the employees toward the customer in a specific instance. The researchers concluded that the personal skills of the employees, the extent to which they were or were not polite, helpful, and friendly, can create a good or bad first impression on the customer. Smith et al. (1999) developed a model of customer satisfaction that takes service failure and recovery into account. They argued that a customer's satisfaction or dissatisfaction may be the result of his/her perceptions of how the service was provided by an establishment's employee or employees. Further, Heskett et al. (1994) developed the service profit chain (SPC), which describes the complex interrelationships between employees in the service industry with service quality ultimately driving both customer satisfaction and loyalty and thus generating profit for the service provider. In an investigation of the SPC in shopping malls, Adeinat and Kassim (2019) found that employee satisfaction leads to external service quality through employee loyalty, which, thereby drives customer satisfaction. Thus, we present Hypothesis 6:

\section{H6: Competent, friendly staff have a positive effect on customer satisfaction.}

\section{Research Methodology}

\subsection{Instrument and Measurement}

The purpose of this study is to determine the service quality attributes in shopping mall food courts that drive customer satisfaction in relation to mall attributes and restaurant attributes. In the area of restaurant service quality, a large body of research focuses on the assessment of service quality at restaurants using two well-known instruments-SERVQAL (Parasuraman et al., 1985) and DINSERV (Stevens et al., 1995) - both of which are applicable to a broad range of settings. However, many of the dimensions are not relevant to the present study. Therefore, we consider only dimensions that are directly applicable to the context addressed herein. In this regard, several researchers have developed their own instruments for restaurants in a similar setting to shopping mall food court.

For example, Kwun (2011) assessed the impact of campus food service attributes on customer satisfaction and identified multiple dimensions, including service quality, food quality, menu, and facility. In the same line, Kim, Moreo, and Yeh (2006) also assessed university food courts and included other dimensions related to dining halls in their account. The dimensions they assessed were service quality, menu, atmosphere, food quality and convenience.

Most of the research studies related to shopping malls do not include an assessment of the quality of the food service in that context. However, generally several attributes that drive customer satisfaction are assessed such as the mall's image, attractiveness, and functionality as an ecosystem. For example, Teller (2008) identified nine dimensions of customer satisfaction (accessibility, parking, retail tenant mix, non-retail tenant mix, merchandise value, personnel, atmosphere, orientation, and infrastructure. However, Ali (2013) identified other attributes such as entertainment, variety, mall essence, and design.

Based on the previous research and several discussions with shopping mall managers, we identified two groups of dimensions, one related to shopping malls and their attributes, comprising ambience, convenience, and restaurant variety, and the other related to tenants in the food court, comprising price, food quality, and staff.

The questionnaire we developed relied on a 7-point Likert scale of 1 for "Strongly Disagree," 2 for "Somewhat Disagree," 3 for "Slightly Disagree,"4 for "Neither Agree Nor Disagree," 5 for "Slightly Agree," 6 for "Somewhat Agree," and 7 for "Strongly Agree." Next, we discuss the measures used in our questionnaire.

Ambience (AMB). AMB refers to the quality of the surrounding space as perceived by the customers (Liu \& Jang, 
2009). We assessed ambience using a 6-item instrument adapted from Kim et al. (2006), Kwun (2011), and Raajpoot (2002) in which respondents were to indicate their perceptions of the availability of seating, the decor, the comfort of the seating area, the temperature, the lighting level, the noise level, and the cleanliness of the food court.

Convenience (CONV). CONV refers to customers' perceptions of the time and effort they must expend in order to visit a given service location. We assessed convenience using a 6-item instrument adapted from Kim et al. (2006) and Jones, Mothersbaugh, and Beatty (2003) in which respondents were asked to indicate their perceptions of the suitability of the location, the hours of operation, the menu signs, and the extent to which the menu was user-friendly.

Restaurants variety (VAR). VAR refers to the mix of tenants in the food court, this will reflect the different cuisines and chains available in the food court. We assessed restaurants variety using a 2-item instrument adapted from Kim et al. (2006) and Kwun (2011) in which the respondents were asked to indicate their perceptions of the availability of the number of food choices and the availability of food choices for special dietary needs such as low fat or diabetes.

Price (PRC). PRC refers to merchandise value. We assessed PRC using a 3-item instrument adapted from Law et al. (2004) in which the respondents were asked to indicate their perceptions of the prices in terms of how reasonable they were and how acceptable. In addition, in relation to price, respondents were asked their perceptions of flexibility to changes in prices.

Food quality (QUAL). QUAL refers to the quality of the food served. We assessed PRC using a 4-item instrument adapted from Kim et al. (2006), Kwun (2011), and Stevens et al. (1995) in which the respondents were asked to indicate their perceptions of the quality, appearance, and taste/flavor of the food, as well as the consistency of the food quality.

Staff (STAFF). STAFF refers to the extent to which a restaurant's employees were competent and approachable. We assessed staff using a 6-item instrument adapted from Kwun (2011) and Stevens et al. (1995) in which the respondents were asked to indicate their perceptions of the following statements: "The restaurant's employees are clean and neat"; "are friendly"; "are able to and willing to give information"; "provide quick service"; "are well trained, competent, and experienced"; and "serve food exactly as you ordered."

The data were collected using a self-administered questionnaire. Originally written in English, the instrument was translated from English into Arabic and back-translated to ensure semantic equivalence. It was then administered in both the English and Arabic versions. Prior to the main data collection, the questionnaires were pre-tested with several experts and some prospective respondents. During the pre-testing exercise, the experts and the prospective respondents were requested to make constructive comments on various aspects of the questionnaire such as sentence structure, diction, format, and length. Based on their feedback, the questionnaire was refined and revised accordingly. Subsequently, the questionnaire was pilot-tested with 30. Using IBM SPSS version 20, we analyzed the responses of these 30 shoppers to assess the reliability of the measurements. The recorded Cronbach $\alpha$ values for all the variables with multi-items were well above 0.7, which suggests that the questionnaire was reliable (Table 1).

Table 1. Operational Definition and Sources of the Measurements of the Variables

\begin{tabular}{lll}
\hline Variables & Sources of measurement & Cronbach alpha of pilot test \\
\hline Ambience & Kim et al. (2006), Kwun et al. (2011), Raajpoot (2002) & 0.807 \\
Staff & Kwun (2011), Stevens et al. (1995) & 0.892 \\
Satisfaction & Kwun (2011) & 0.811 \\
Food Quality & Kim et al. (2006), Kwun (2011), Stevens et al. (1995) & 0.849 \\
Convenience & Kim et al. (2006), Jones, Mothersbaugh \& Beatty (2003), \\
Price & Law et al. (2004) & 0.846 \\
Variety & Kim et al. (2006), Kwun (2011) & 0.842 \\
\hline 3.2 Participants & & 0.679
\end{tabular}

This study was conducted in 7 shopping malls in Jeddah, Saudi Arabia. These malls are considered the largest malls in the Jeddah. These malls were also considered due to the diversity of the retail stores and restaurants. We invited people who were dining in the food courts shoppers to complete a self-administered questionnaire. We collected 397 questionnaires within a period of 3 months, starting from July 2019, of which 95 were incomplete 
such that we discarded them. The final sample subjected to analysis consisted of 303 questionnaires - a sample size considered appropriate for establishing validity and reliability in the context of the present research study (Costello \& Osborne, 2005).

\section{Findings}

\subsection{Respondents' Profile}

Based on the final sample, the ratio of males to females was 29 to $71 \%$. The gender distribution suggests that women have a significantly greater presence in the food court, which is consistent with their household roles, which lead them to patronize food courts more frequently than men do. The age distribution of the respondents was as follows: respondents aged 15 to 20 accounted for $10.2 \%$ of the sample; respondents aged 21 to 30 for $18.4 \%$; respondents aged $31-40$ for $32 \%$; respondents aged $41-50$ for $36.4 \%$; and respondents of 50 years and above for $3 \%$. The age distribution indicates the dominance of households with respondents older than 31 years of age (almost 68\%). In regard to marital status, $95 \%$ of the respondents were married and 5\% single (it is probable that the latter were mall employees eating at the food court on their break). Finally, the frequency of food court visits and the average time spent in the food court area are reported in Table 2.

Table 2. Respondents' Profile

\begin{tabular}{|c|c|c|c|c|c|}
\hline & Frequency & $\%$ & & Frequency & $\%$ \\
\hline \multirow{2}{*}{\multicolumn{2}{|c|}{ Frequency of dining in a food court }} & & \multicolumn{3}{|c|}{ Average time spent in the food court } \\
\hline & 27 & 8.9 & Below $30 \mathrm{~min}$ & 25 & 8.25 \\
\hline Few times a week & 78 & 25.7 & $31-59 \mathrm{~min}$ & 93 & 30.69 \\
\hline Few times a month & 135 & 44.6 & $60-74 \mathrm{~min}$ & 109 & 35.97 \\
\hline Occasionally & 62 & 20.5 & 75 min or more & 76 & 25.08 \\
\hline Once a year & 1 & 0.3 & & & \\
\hline
\end{tabular}

4.2 Assessment of Convergent and Discriminant Validity

We followed a two-step approach to estimate the measurement model, and then we constructed the structural model (Anderson \& Gerbing, 1988). First, we performed a confirmatory factor analysis (CFA) to determine whether the measurement variables reliably reflected the hypothesized latent variables. Second, we performed SEM with latent variables via AMOS to determine the adequacy of the model constructs for testing the hypotheses.

We performed our exploratory factor analysis using Varimax rotation with Kaiser Normalization and maximum likelihood with a cutoff of 0.60 to identify items that loaded "substantially" on a factor. As a result, seven factors were extracted as expected, namely, customer satisfaction, ambience, convenience, restaurant variety, staff, food quality, and price. The factor loading value above 0.7 also supports the convergent validity, as shown in Table 3 .

Table 3. Convergent Validity Results

\begin{tabular}{lllll}
\hline Constructs & $\begin{array}{l}\text { Measurement } \\
\text { items }\end{array}$ & $\begin{array}{l}\text { Factor } \\
\text { loading }\end{array}$ & $\begin{array}{l}\text { Composite } \\
\text { reliability (CR) }\end{array}$ & $\begin{array}{l}\text { Average variance } \\
\text { extracted (AVE) }\end{array}$ \\
\hline Customer satisfaction & SAT3 & 0.754 & 0.811 & 0.518 \\
& SAT4 & 0.750 & & \\
SAT1 & 0.725 & & 0.602 \\
Ambience & SAT2 & 0.714 & & \\
& AMB2 & 0.835 & 0.751 & 0.637 \\
Convenience & AMB1 & 0.827 & & \\
& CONV2 & 0.762 & 0.840 & 0.561 \\
Restaurant variety & CONV1 & 0.760 & & 0.676 \\
Staff & CONV3 & 0.670 & & \\
& VAR 1 & 0.887 & 0.711 & \\
VAR 2 & 0.746 & \multirow{2}{*}{0.893} & \\
Food quality & SATFF3 & 0.815 & & \\
& SATFF2 & 0.759 & & \\
SATFF1 & 0.725 & & \\
SATFF4 & 0.718 & \multirow{2}{*}{0.855} & \\
QUAL3 & 0.748 & & 0.732 \\
\hline
\end{tabular}

To assess the convergent validity further, we performed a CFA and assessed the composite reliability (CR) and average variance extracted (AVE). In terms of CR, all the scores are well above the cutoff value of 0.6 
recommended by Hair et al. (2010). Fornell and Larcker (1981) suggested no more than 0.5 as an acceptable level of AVE, which is also fulfilled in this study (Table 2). The conditions for establishing discriminant validity were also met: Table 4 shows that the value of the square root of the AVE is well above the correlation values with all the other variables and the maximum shared variance (MSV) for each construct lower than the AVE. This result suggests that the measurement has adequate convergent and discriminant validity.

Table 4. Discriminant Validity Results

\begin{tabular}{llllllllll}
\hline & AVE & MSV & (1) & (2) & (3) & (4) & (5) & (6) & (7) \\
\hline (1) Ambiance & 0.602 & 0.280 & 0.776 & & & & & & \\
(2) Staff & 0.676 & 0.601 & 0.504 & 0.822 & & & & & \\
(3) Satisfaction & 0.518 & 0.462 & 0.429 & 0.592 & 0.719 & & & & \\
(4) Food quality & 0.597 & 0.590 & 0.529 & 0.768 & 0.680 & 0.773 & & & \\
(5) Convenience & 0.637 & 0.601 & 0.403 & 0.775 & 0.637 & 0.712 & 0.798 & & \\
(6) Food price & 0.732 & 0.320 & 0.390 & 0.420 & 0.387 & 0.566 & 0.487 & 0.855 & \\
(7) Food variety & 0.561 & 0.255 & 0.408 & 0.338 & 0.462 & 0.505 & 0.436 & 0.491 & 0.749 \\
\hline
\end{tabular}

Note: $\mathrm{CR}=$ composite reliability; AVE=average variance extracted; MSV=maximum shared variance. Values below the diagonal are correlation estimates between factors, and the diagonal elements are the square root of AVE.

\subsection{Overall Model Goodness of Fit}

In order to examine our hypotheses, we developed a structural model. Before discussing the results of the path estimates, we report the goodness-of-fit of the SEM. The results show that the Chi-square value $\left(\chi^{2}=307.002\right.$, DOF $=168)$ was highly significant at $p=0.00$ level. Further, the value of $\left(\chi^{2} / d f\right)$ was found to be 1.827 , which is lower than 5.00. The NFI value was 0.913 , and the CFI value 0.958 , both above the acceptable range. The RMSEA value was 0.052 , i.e., lower than 0.1 , which indicates a good fit. Overall, with the other fit measures shown in Table 5, the results show that the overall fit of the proposed model represents an acceptable overall goodness of fit for the research model.

Table 5. Fit Indices of the Structural Model

\begin{tabular}{lll}
\hline Goodness of fit measure & Recommended value & Values \\
\hline Chi-square $\left(\chi^{2}\right)$ of estimated model & & 307.002 \\
Degree of freedom $(d f)$ & $\geq 0.5$ & 168 \\
P-value (probability) & $\leq 5.0$ & 0.00 \\
Chi-square/degree of freedom $\left(\chi^{2} / d f\right)$ & $\geq 0.90$ & 1.827 \\
Goodness of fit index (GFI) & $\leq 0.05$ & 0.912 \\
Root mean square residual (RMR) & $\leq 0.10$ & 0.041 \\
Root mean square residual (RMSR) & $\geq 0.90$ & 0.052 \\
Normed fit index (NFI) & $\geq 0.90$ & 0.913 \\
Comparative fit index (CFI) & $\geq 0.80$ & 0.958 \\
Adjusted goodness of fit index (AGFI) & $\geq 0.50$ & 0.879 \\
Parsimonious normed fit index (PNFI) & & 0.730 \\
\hline
\end{tabular}

4.4 SEM Model Analysis

Figure 1 and Table 6 show the standardized path coefficient $(\beta)$ of the structural model. In regard to the mall attribute, only $\mathrm{H} 2$ and $\mathrm{H} 3$ were supported at $\mathrm{p}<.001$. More specifically, the results indicate that restaurant variety in the food court is positively related to customer satisfaction $(\beta=0.14, t=1.797)$, and the convenient location of the food court in the shopping mall is positively related to customer satisfaction $(\beta=0.30, t=2.637)$, whereas the ambiance of the food court was found to have a significant role in driving customer satisfaction. These results may not be surprising, as most shopping malls in Saudi Arabia are characterized as modern and shoppers think of them as order qualifier more than order winner.

On the other hand, the results regarding the food court's restaurant attributes suggest that only food quality had a 
significant effect on customer satisfaction, thereby supporting $H 5(\beta=0.41, t=3.316)$, whereas the effect of food price on customer satisfaction was insignificant and the staff working in theses restaurants did not have any significant effect on customer satisfaction, thus $\mathrm{H} 4$ and $\mathrm{H} 6$ were not supported.

Table 6. Structural Path Estimates

\begin{tabular}{lllllccl}
\hline & & & & \multicolumn{2}{c}{ Effect $(\beta)$ Result } & \\
\cline { 4 - 6 } Hypothesis & & \multicolumn{2}{c}{ Path } & & Standardized estimate & t- value & \\
\hline H1 & SAT & $<---$ & AMB & 0.068 & 0.885 & Not supported \\
H2 & SAT & $<---$ & VAR & 0.140 & $1.797^{*}$ & Supported \\
H3 & SAT & $<---$ & CONV & 0.298 & $2.637^{* * *}$ & Supported \\
H4 & SAT & $<---$ & PRC & -0.086 & -1.140 & Not supported \\
H5 & SAT & $<---$ & QUAL & 0.409 & $3.316^{* * *}$ & Supported \\
H6 & SAT & $<---$ & STAFF & 0.001 & 0.008 & Not supported \\
\hline
\end{tabular}

Note: $\mathrm{AMB}=$ ambiance; $\mathrm{VAR}=$ variety; $\mathrm{CONV}=$ convenience; $\mathrm{PRC}=$ price; $\mathrm{QUAL}=$ quality

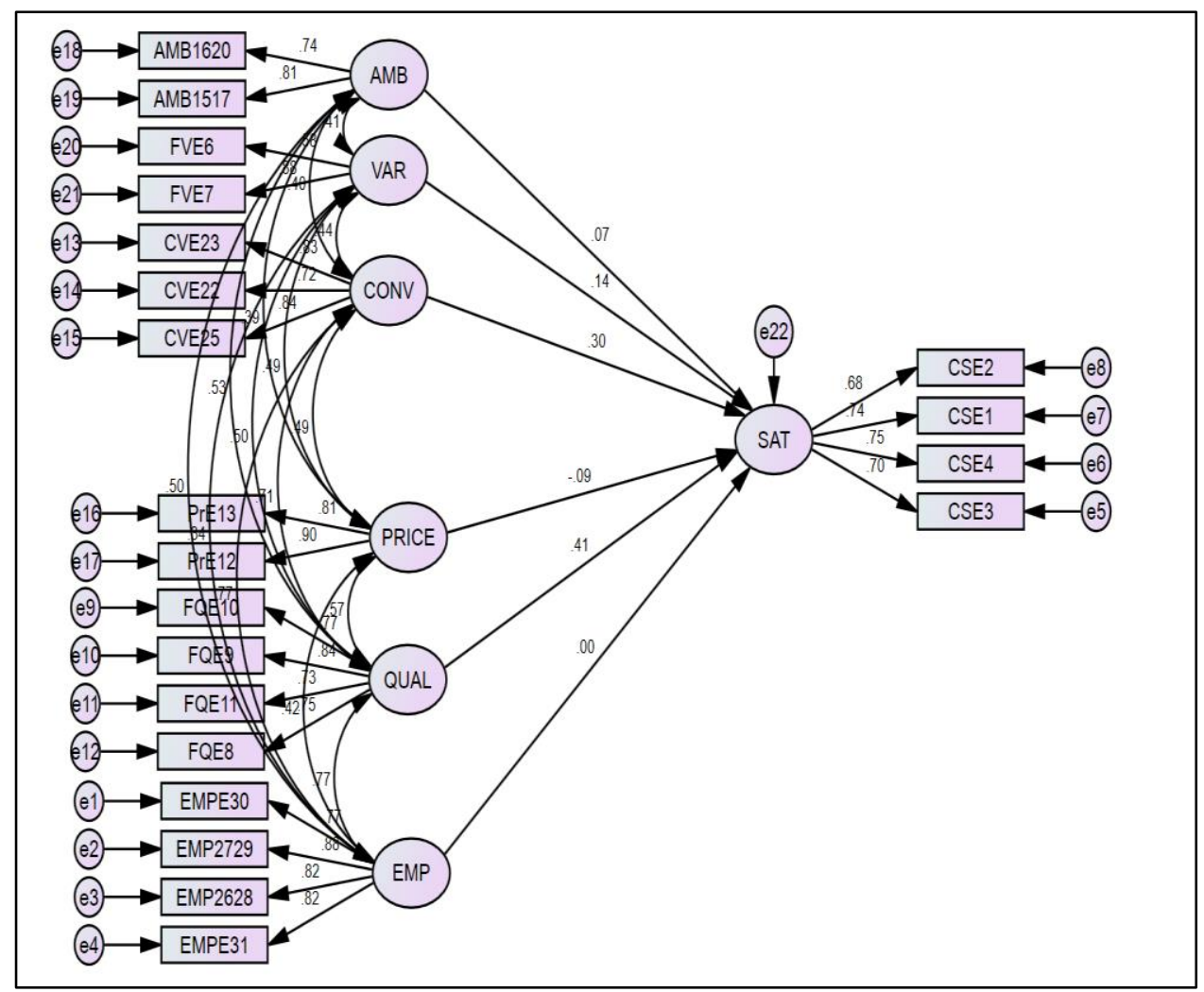

Figure 1. Standardized Coefficient (Shopping Mall Food Court)

Notes: SAT: Satisfaction, AMB: Ambiance, VAR: Variety, CONV: Convenience, QUAL: Quality, EMP: Staff

\section{Conclusion}

In this study, we assessed the service quality of a food court by identifying several attributes related to the food court itself and other attributes related to the food served. Shopping malls play a central role in the retail ecosystem by bringing together groups of shoppers and retailers. According to the S-D logic approach, companies' survival in a network economy requires the ability to learn, adapt, and change in order to integrate resources with other actors and to offer competitively compelling value propositions to customers (Lusch, Vargo, \& Tanniru, 2010).

To assess the factors driving customer satisfaction, we considered six attributes in our analysis, which we divided into two groups. The first group related to the ambience, food variety, and convenience of the food court, whereas the second group related to the quality of the food, the price of the food, and the employees working in 
the food court restaurants.

According to our analysis, food quality was the factor most responsible for driving customer satisfaction, followed by the convenience of the location and then food variety. The ambience of the food court, the price of the food, and the behavior of the employees did not have a significant effect on customer satisfaction. Many studies have shown that the ambience of shopping malls plays an important role in driving customer satisfaction. Yet, in the present study, customers were not shown to assign great value to ambience in the food court setting. It can be argued, however, that the results presented here pertain only to the culture of Saudi Arabia, where large-scale modern malls are the norm. However, the results showing that customers do not pay much attention to ambience in shopping mall food courts do not mean that this factor should become unimportant to shopping malls. It remains important to create and maintain all the conditions that support customer satisfaction. On this basis, ambience remains important to customer satisfaction. It can even be argued that customers may not be particularly aware of it, but perhaps would become so if the ambience was such as to create a negative experience.

Food price did not have any significant relationship with customer satisfaction. This result could also be explained by the kinds of restaurants that dominate the mall food court environment. That is, there are very few local and specialty places, and most of the establishments are chain fast food restaurants. Given that customers' perceptions of the food price at these restaurants are already known, food price would not generally drive their satisfaction level as customers take it for granted.

The results reported in this research paper have important implications for developers of malls. Specifically, the results suggest that malls be planned with a focus on the attributes that are most valued by customers-food quality, food variety, and a 'convenient location for the food court. Such an emphasis may render malls built accordingly more attractive to consumers. The information provided herein provides a basis for setting priorities when working with non-retail tenants in relation to establishing food quality policies and maintaining a consistent level of quality.

Finally, the present study is based on only one country. Hence, the results reported cannot be generalized to the entire industry, as shopping malls differ from country to country. In addition, we explored only six attributes of food courts, although a number of additional variables have been identified (Idoko et al., 2019; Raajpoot, 2002). Therefore, more extensive research using a range of models and approaches is required in order to secure knowledge about the multinational and multifactor variations of restaurants in similar settings such dining halls on university campuses and restaurant amenities at airports.

\section{References}

Adeinat, I., \& Kassim, N. (2019). Extending the service profit chain: The mediating effect of employee productivity. International Journal of Quality \& Reliability Management, 36(5), 797-814. https://doi.org/10.1108/IJQRM-03-2018-0064

Ahmad, A. E. M. K. (2012). Attractiveness Factors Influencing Shoppers Satisfaction, Loyalty, and Word of Mouth: An Empirical Investigation of Saudi Arabia Shopping Malls. International Journal of Business Administration, 3(6), 101-112. https://doi.org/10.5430/ijba.v3n6p101

Ailawadi, K. L., \& Keller, K. L. (2004). Understanding retail branding: conceptual insights and research priorities. Journal of retailing, 80(4), 331-342. https://doi.org/10.1016/j.jretai.2004.10.008

Ali, K. A. M. (2013). A structural equation modeling approaches on factors of shopping mall attractiveness that influence consumer decision-making in choosing a shopping mall. Journal of Global Business \& Economics, 6(1), 63-76.

Anderson, J. C., \& Gerbing, D. W. (1988). Structural equation modeling in practice: A review and recommended two-step approach. Psychological bulletin, 103(3), 411. https://doi.org/10.1037/0033-2909.103.3.411

Azanza, M. P. V. (2001). Food consumption and buying patterns of students from a Philippine university fastfood mall. International journal of food sciences and nutrition, 52(6), 515-520. https://doi.org/10.1080/09637480020027000-6-4

Babin, B. J., \& Darden, W. R. (1995). Consumer self-regulation in a retail environment. Journal of retailing 71(1), 47-70. https://doi.org/10.1016/0022-4359(95)90012-8

Baker, J., Grewal, D., \& Parasuraman, A. (1994). The influence of store environment on quality inferences and store image. Journal of the Academy of Marketing Science, 22(4), 328-339.

https://doi.org/10.1177/0092070394224002 
Bitner, M. J., Booms, B. H., \& Tetreault, M. S. (1990). The service encounter: diagnosing favorable and unfavorable incidents. Journal of marketing, 54(1), 71-84. https://doi.org/10.1177/002224299005400105

Cao, Y., \& Kim, K. (2015). How do customers perceive service quality in differently structured fast food restaurants? Journal of Hospitality Marketing \& Management, 24(1), 99-117. https://doi.org/10.1080/19368623.2014.903817

Chebat, J. C., Sirgy, M. J., \& Grzeskowiak, S. (2010). How can shopping mall management best capture mall image?. Journal of Business Research, 63(7), 735-740. https://doi.org/10.1016/j.jbusres.2009.05.009

Costello, A. B., \& Osborne, J. (2005). Best practices in exploratory factor analysis: Four recommendations for getting the most from your analysis. Practical assessment, research, and evaluation, 10(1), 7.

Das, G., \& Varshneya, G. (2017). Consumer emotions: Determinants and outcomes in a shopping mall. Journal of Retailing and Consumer Services, 38, 177-185. https://doi.org/10.1016/j.jretconser.2017.06.008

Diallo, M. F., Diop-Sall, F., Djelassi, S., \& Godefroit-Winkel, D. (2018). How shopping mall service quality affects customer loyalty across developing countries: the moderation of the cultural context. Journal of International Marketing, 26(4), 69-84. https://doi.org/10.1177/1069031X18807473

El Hedhli, K., Chebat, J. C., \& Sirgy, M. J. (2013). Shopping well-being at the mall: Construct, antecedents, and consequences. Journal of business research, 66(7), 856-863. https://doi.org/10.1016/j.jbusres.2011.06.011

Fornell, C., \& Larcker, D. F. (1981). Structural equation models with unobservable variables and measurement error: Algebra and statistics. https://doi.org/10.2307/3150980

Hair, J. F., Anderson, R. E., Babin, B. J., \& Black, W. C. (2010). Multivariate data analysis: A global perspective.

Heskett, J. L., Jones, T. O., Loveman, G. W., Sasser, W. E., \& Schlesinger, L. A. (1994). Putting the service-profit chain to work. Harvard business review, 72(2), 164-174.

Idoko, E. C., Ukenna, S. I., \& Obeta, C. E. (2019). Determinants of shopping mall patronage frequency in a developing economy: Evidence from Nigerian mall shoppers. Journal of Retailing and Consumer Services, 48, 186-201. https://doi.org/10.1016/j.jretconser.2019.02.001

Jones, M. A., Mothersbaugh, D. L., \& Beatty, S. E. (2003). The effects of locational convenience on customer repurchase intentions across service types. Journal of Services Marketing, 17(7), 701-712. https://doi.org/10.1108/08876040310501250

Josiam, B. M., Malave, R., Foster, C., \& Baldwin, W. (2017). Assessing quality of food, service and customer experience at a restaurant: The case of a student-run restaurant in the USA. In Hospitality Marketing and Consumer Behavior (pp. 129-156). https://doi.org/10.1201/9781315366227-6

Keller, K. L. (2003). Brand synthesis: The multidimensionality of brand knowledge. Journal of consumer research, 29(4), 595-600. https://doi.org/10.1086/346254

Khong, K., \& Sim Ong, F. (2014). Shopper perception and loyalty: a stochastic approach to modelling shopping mall behavior. International Journal of Retail \& Distribution Management,42(7), 626-642. https://doi.org/10.1108/IJRDM-11-2012-0100

Kim, W. G., Ng, C. Y. N., \& Kim, Y. S. (2009). Influence of institutional DINESERV on customer satisfaction, return intention, and word-of-mouth. International Journal of Hospitality Management, 28(1), 10-17. https://doi.org/10.1016/j.ijhm.2008.03.005

Kim, Y. S., Hertzman, J., \& Hwang, J. J. (2010). College students and quick-service restaurants: How students perceive restaurant food and services. Journal of foodservice business research, 13(4), 346-359. https://doi.org/10.1080/15378020.2010.524536

Kim, Y. S., Moreo, P. J., \& Yeh, R. J. (2006). Customers' satisfaction factors regarding university food court service. Journal of Foodservice Business Research, 7(4), 97-110. https://doi.org/10.1300/J369v07n04_05

Klassen, K. J., Trybus, E., \& Kumar, A. (2005). Planning food services for a campus setting. International journal of hospitality management, 24(4), 579-609. https://doi.org/10.1016/j.ijhm.2005.01.001

Kuo, T., Chen, C. T., \& Cheng, W. J. (2018). Service quality evaluation: moderating influences of first-time and revisiting customers. Total Quality Management \& Business Excellence, 29(3-4), 429-440. https://doi.org/10.1080/14783363.2016.1209405

Kwun, D. J. W. (2011). Effects of campus foodservice attributes on perceived value, satisfaction, and consumer 
attitude: A gender-difference approach. International Journal of Hospitality Management, 30(2), 252-261. https://doi.org/10.1016/j.ijhm.2010.09.001

Law, A. K., Hui, Y. V., \& Zhao, X. (2004). Modeling repurchase frequency and customer satisfaction for fast food outlets. International journal of quality \& reliability management, 21(5), 545-563. ttps://doi.org/10.1108/02656710410536563

Liu, Y., \& Jang, S. S. (2009). The effects of dining atmospherics: An extended Mehrabian-Russell model. International journal of hospitality management, 28(4), 494-503. https://doi.org/10.1016/j.ijhm.2009.01.002

Lusch, R. F., Vargo, S. L., \& Tanniru, M. (2010). Service, value networks and learning. Journal of the academy of marketing science, 38(1), 19-31. https://doi.org/10.1007/s11747-008-0131-z

Namkung, Y., \& Jang, S. C. S. (2007). Does food quality really matter in restaurants? Its impact on customer satisfaction and behavioral intentions. Journal of Hospitality \& Tourism Research, 31(3), 387-409. https://doi.org/10.1177/1096348007299924

Parasuraman, A., Zeithaml, V. A., \& Berry, L. L. (1985). A conceptual model of service quality and its implications for future research. The Journal of Marketing, 41-50. https://doi.org/10.1177/002224298504900403

Qin, G., \& Prybutok, V. R. (2008). Determinants of customer-perceived service quality in fast-food restaurants and their relationship to customer satisfaction and behavioral intentions. Quality Management Journal, 15(2), 35-50. https://doi.org/10.1080/10686967.2008.11918065

Raajpoot, N. A. (2002). TANGSERV: A multiple item scale for measuring tangible quality in foodservice industry. Journal of Foodservice Business Research, 5(2), 109-127. https://doi.org/10.1300/J369v05n02_08

Ryu, K., Lee, H. R., \& Gon Kim, W. (2012). The influence of the quality of the physical environment, food, and service on restaurant image, customer perceived value, customer satisfaction, and behavioral intentions. International journal of contemporary hospitality management, 24(2), 200-223. https://doi.org/10.1108/09596111211206141

Singh, H., \& Prashar, S. (2013). Factors defining shopping experience: an analytical study of Dubai. Asian Journal of Business Research, 3(1). https://doi.org/10.14707/ajbr.130003

Smith, A. K., Bolton, R. N., \& Wagner, J. (1999). A model of customer satisfaction with service encounters involving failure and recovery. Journal of marketing research, 36(3), 356-372. https://doi.org/10.1177/002224379903600305

Smith, P., \& Burns, D. (1996). Atmospherics and retail environments: the case of the power aisle. International Journal of Retail \& Distribution Management, 24(1), 7-14. https://doi.org/10.1108/09590559610107076

Stevens, P., Knutson, B., \& Patton, M. (1995). DINESERV: A tool for measuring service quality in restaurants. The Cornell Hotel and Restaurant Administration Quarterly, 36(2), 5-60. https://doi.org/10.1016/0010-8804(95)93844-K

Sulek, J. M., \& Hensley, R. L. (2004). The relative importance of food, atmosphere, and fairness of wait: The case of a full-service restaurant. Cornell Hotel and Restaurant Administration Quarterly, 45(3), 235-247. https://doi.org/10.1177/0010880404265345

Susskind, A. M., \& Chan, E. K. (2000). How restaurant features affect check averages. Cornell Hotel and Restaurant Administration Quarterly, 41(6), 56-63. https://doi.org/10.1177/001088040004100608

Teller, C. (2008). Shopping streets versus shopping malls-determinants of agglomeration format attractiveness from the consumers' point of view. The International Review of Retail, Distribution and Consumer Research, 18(4), 381-403. https://doi.org/10.1080/09593960802299452

Tsai, Y. H. (2018). Simplified structural modeling of loyalty acquisition based on the conceptual clustering model. Cluster Computing, 21(1), 879-892. https://doi.org/10.1007/s10586-017-0939-8

Vargo, S. L., \& Lusch, R. F. (2016). Institutions and axioms: an extension and update of service-dominant logic. Journal of the Academy of marketing Science, 44(1), 5-23. https://doi.org/10.1007/s11747-015-0456-3

Wall, E. A., \& Berry, L. L. (2007). The combined effects of the physical environment and employee behavior on customer perception of restaurant service quality. Cornell hotel and restaurant administration 
quarterly, 48(1), 59-69. https://doi.org/10.1177/0010880406297246

Wright, T. L., Newman, A., \& Dennis, C. (2006). Enhancing consumer empowerment. European Journal of Marketing, 40(9/10), 925-935. https://doi.org/10.1108/03090560610680934

Wu, H. C., \& Mohi, Z. (2015). Assessment of service quality in the fast-food restaurant. Journal of Foodservice Business Research, 18(4), 358-388. https://doi.org/10.1080/15378020.2015.1068673

Yiu, C. Y., \& Xu, S. Y. (2012). A tenant - mix model for shopping malls. European Journal of Marketing. https://doi.org/10.1108/03090561211202594

Yiu, C. Y., \& Yau, Y. (2006). An ecological framework for the strategic positioning of a shopping mall. Journal of Retail \& Leisure Property, 5(4), 270-280. https://doi.org/10.1057/palgrave.rlp.5100037

\section{Copyrights}

Copyright for this article is retained by the author(s), with first publication rights granted to the journal.

This is an open-access article distributed under the terms and conditions of the Creative Commons Attribution license (http://creativecommons.org/licenses/by/4.0/). 